\title{
NUTRITIONAL STUDIES INCLUDING QUANTITATIVE MINERAL REQUIREMENTS OF THE ALMOND MOTH, Cadra cautella (LEPIDOPTERA: PYRALIDAE)
}

By

W. CRAIG STEVENS

A DISSERTATION PRESENTEd TO THE GRADUATE COUNCIL OF THE UNIVERSITY OF FLORIDA

IN PARTIAL FULFILLMENT OF THE REQUIREMENTS FOR THE DEGREE OF DOCTOR OF PHILOSOPHY

UNIVERSITY OF FLORIDA 


\section{ACKNOWLEDGINNTS}

The author expresses his appreciation to Dr. R. E. Waites for serving as chairman of the supervisory comittee during his cour'se of study, his assistance and expenditures of time.

A note of thanks is due Dr. James Nation for the use of his laboratory ano special instruction on the use of the atomic absorption spectrophotometer, without which this study could not have been made.

I wish to thank Doctors F. S. Blanton, D. H. Habeck, Jerry Butler, W. G. Eden and E. L. Pierce for serving as committee members.

This investigation was supported in part by the Marlset Quality Research Division Cooperative Agreement No. 12-14-100-8421 (51) from the Agricultural Rescarch Service, U.S.D.A. and by funding from the Dow Chenical Company. 
TABLE OF CONTENTS

Parge

ACKNOWLEDGNENTS. . . . . . . . . . . . . . . . . . . ii

LIST OF TABLES ...................... . . . . V

IIST OF FIGURES. . . . . . . . . . . . . . . . . . . . . vi

ABSTRACT . . . . . . . . . . . . . . . . . . . vii

CHAPTER I

INTRODUCTION. . . . . . . . . . . . . . . . . . . . 1 CHAPTER II

LITERATURE REVIEW . . . . . . . . . . . . . . . . . 3

General Insect Nutrition. . . . . . . . . . . . . 3

Nutrition of Some Stored Product Insects Including the

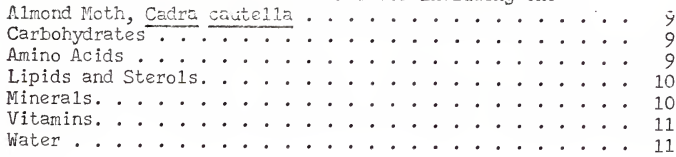

CHAPTER III

MATERIALS AND METHODS . . . . . . . . . . . . . 12

Almond Moth Colonies. . . . . . . . . . . . . . . 12

Atomic Absorption Spectrophotometric Analysis . . . . . . 14

Experimental Diet Preparation . . . . . . . . . . . 15

Statistical Analysis. . . . . . . . . . . . . . 16

Larval Growth Analysis. . . . . . . . . . . . . . . 17

CHAPTER IV

PROCEDURAL PROBLEMS . . . . . . . . . . . . . . . . . . . . 18

Mites . . . . . . . . . . . . . . . . 18 
Microbial Contamination . . . . . . . . . . . . 17

Larval Handling . . . . . . . . . . . . . . . . . . . . 19

Beetle Infestation. . . . . . . . . . . . . . 20 CHAPTER V

EXPERTMENTAL. . . . . . . . . . . . . . . . 21

Preliminary Investigations. . . . . . . . . . . . . 21

Vitamins, Cholesterol and Fats. ........... 21

Amino Acid Studies. . . . . . . . . . . . . . 21

Carbohydrates ....................... 22

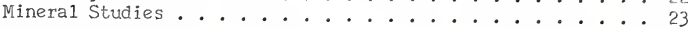

CHAPTER VI

RESULTS AND DISCUSSION. . . . . . . . . . . . . 25 CHAPTER VII

SUMVARY . . . . . . . . . . . . . . . . . 47 REFERENCES CITED . . . . . . . . . . . . . . 48 BIOGRAPHICAL SKETCH. . . . . . . . . . . . . . . 54 


\section{LIST OF TABLES}

1 Comparison of mineral cation requirements of the almond moth with other insects and vertebrates. . . . . . . 30

2 Basic diet for nutritional work with the almond moth (modification of Franke1 and Blewett (1946a) a11 vitamin diet and Beck, Chippendale and Swinton (1968) salt mixture. . . . . . . . . . . . . . . 31

3 Growth of the almond moth on graded levels of amino acids (minimal requirements underlined). ......... 32

4 Summary of the amino acid deletion series (mininal levels

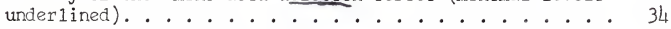

5 Mineral salt composition of the almond moth in different stages of development............... 35

6 Mineral salt content of the standard laboratory rearing thedium for the almond rioth as determirea by aionic absorption spectrophotometry... . . . . . . . . 36

7 Growth of the almond moth on diets with graded nineral

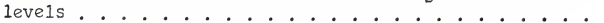

8 Composition of the salt mixture in the mineral control diet for the almond noth and amounts of each cation supplied.

9 Minimal requirements of the almond moth for cations of mineral salts and estimated toxicities.......... 


\section{LIST OF FIGURES}

Figures

Page

1 Laboratory colony of the alnond moth on standard

laborator'y rearing medium. ........... . 42

2 Egg collecting set up for the almond moth. . . . . . 43

3 Mode1 100 Varian Atomic Absorption Spectrophotometer . 44

4 Mode1 43 Varicord recorder ............ 45

5 Boekel Muffle Furnace. . . . . . . . . . . 46 
Abstract of Dissertation Presented to the Graduate Council

of the University of Florida in Partial Fulfillment of the

Requirements for the Degree of Doctor of Philosophy

NUTRITIONAL STUDIES INCLUDING QUANTITATIVE MINERAL, REOUIPEMENTS

OF THE ALMOND MOTH, CAJRA CAUTELLA (IEPIDOPTERA:PYRAI,TDAE)

By

\section{W. Craig Stevens}

August, 1970

Chaiman: Dr. R. E. Waites

Major Department: Entomology and Nematology

Mineral Celetion studies and spectrophotometric analysis of

carcass) tissue was used to determine the mineral requirements for eight cations in the diet of the almond moth, Cadra caute1la (Wa1ker. Tests of ten replicates for each graded mineral level showed the following mineral levels to be optimal: (mg/100 g dry diet) potassium .325; calcium 1.0; sodium .002; iron .01; zinc .0001; magnesium .100 and copper .005 . No relationship is indicated between mineral concentration in carcass tissue and dietary requirements. Luw ievels of zinc, potassium and magnesium produce greater yields. The need for iron in the diet was not distinct. Low calcium levels in diets reduced yields except in the presence of high sodium levels. The need for magnesium is reduced when potassium is included at a high level. A high mortality among larvae occurred when the total mineral concentration exceeded 3 per cent.

Graded levels of 13 amino acids were tested for the almond moth. Protein requirements are similar to other stored product insects and the rat. A distinct need was shown for arginine, $1 \mathrm{Hs}$ ine, leucine and phenylalanine in the diet. Cystine, tryptophan, methionine, glycine, isoleucine, ${ }^{5}{ }^{6} u c i n e,{ }^{7}$ line and glutamic acid are essential in the diet of the almond moth, but to a lesser degree. Histidine was required in 
relatively low amounts, contrary to the requirements of other stored product insects. 
CHAPTER I

INTRODUCTION

Al1 findings reported here were done with the almond moth, Cadra cautella (Walker) (Lepidoptera:Pyralidae). This species is a common pest of dried fruits, nuts, tobacco, cocoa beans and citrus throughout the world (Franke1 and Blewett 1946a, Beck 1930, Ethe1ston 1964, Wadsworth 1933).

The adult almond moth is gray-brown in color, $3-5 \mathrm{~mm}$ long, with a life span of approximately 18 days. Only immatures feed. Copulation occurs shortly after emergence, and egg laying begins within eight hours. Eggs are deposited directly on the surface of the medium at the rate of $1.03 \mathrm{mg}$ per moth (Strong, Partida and Warner 1968). There are three molts prior to the pupal stage.

The almond moth was previously classified in the genus Ephestia; however, Walley (1960) determined the species to be in the genus Cadra.

The almond moth and closely related species have been used by nutritional, genetic, biochenical and ecological investigators as a test organism as early as 1921 (Whiting 1921, Williams 1938, Wadsworth 1933). The primary purpose of this study was to contribute to the know $1-$ edge of insect nutrition in general, and to determine the specific mineral requirements for the almond moth.

The almond moth has proven to be an ideal test organism for nutri- 
tional experiments. It has been shown that lower forms such as the alnond moth can be used more simply than higher forms to investigate biochemical phenomena common to all animals including man (Medici 1964). 
CHAPTER II

\section{LITERATURE REVIEW}

\section{Genera.1 Insect Nutrition}

Insects feed on a wide variety of organic matter. Their diets range from forest litter, or fungi growing on the litter, to living tissue of animals or man. Many insects are relatively omnivorous, but the majority are largely selective in their diet and choice of food and will develop and thrive only after they feed on that portion of the plant or animal which satisfies their particular need.

A basic knowledge of what the insect eats and what is assimilated is the underlying structure on which to build an understanding of the nutritional recuirements. How much of a given substance is necessary to support nornat growth, development, minlenance, reproduction and what effects do quality and quantity have on the insect's physiological processes? These questions are largely unanswered, but more and more attention is being directed toward their solution.

Not until the twentieth century has there been significant work on insect nutrition; however, Loeb (1915) did some studies on the nutrition of Drosophila melanogaster Meigen. Chapman (1923) reported on gut symbionts of the confused flour beetle, Tribolium confusum Duva1, and suggested additional investigations be made on the nutrition of this insect. The literature on insect nutrition is extensive. Some of the more recent reviews are by Lipke and Franke1 (1956), House (1961, 1962), Dadd (1963) and Friend (1962). Nutrition of closely related groups such 
as the Acarina is reported by Rodriguez (1964, 1966).

Of the more than one million described species of insects, few have been investigated for mineral requirements. Insects that feed on plant tissues, the larvae of flies and mosquitoes and stored product pests have received the most attention. Parasitic and predacious insect nutrition has been largely neglected (Frankel 1959:4).

In early nutritional studies, natural products, mainly host plants, were included in diets, thus 1 imiting the knowledge attainable from such studies; however, workers have begun to replace the crude components with known ones. The twentieth century has been the age of sophistication in technique. Improved research equipment such as the atomic absorption spectrophotometer, the gas chromatograph, the amino acid analyzor and other instrumentation has lessened the problems of the investigator; however, many problems remain.

Few, if any, diets for insects have been reported as chomically pure. Those reported as pure have undefined components such as casein, wheat gern and yeast. These components are not derined chemicaliy but contain complex amino acids, fatty acids, vitamins, mineral salts and other unknown constituents.

Insect diets having undefined components have been reported by Beck and Stauffer (1950); Sang (1956); Jensen (1962); Pausch (1962); Vanderzant (1963); Beck, Chippendale and Swinton (1968). The axenic technique has been used for only a few of the chemically defined diets reported to date (House 1961; Friend, Backs and Cass 1957; Friend, Salkeld and Stevenson 1959). A diet has been reported as chemically pure for the two spotted spider mite, Tetranychus urticae Koch (Rodriguez and Hampton 1966). Defined diets have been reported 
for the 1ocust Schistocera gregaria Scudder (Dadd 1961, 1963), the aphid Myzus persicae Sulzer (Dadd and Mittle1 1966), the boll weevil Anthonomus grandis Boheman (Vanderzant 1963), the confused flour beetle Triboliun Confusum Duval (Taylor and Medici 1966, Medici and Taylor 1966).

Rock and King (1967) reported the amino acid requirements for the codling moth. Medici and Taylor (1967) reported inter-relationships between certain minerals for the confused flour beetle. Franke1 and Blewett (1946a) reported the role of fatty acids for Tineola bisse11ie11a Humme1.

Numerous technological innovations have been incorporated into nutritional investigations during the past decade. Examples of technological advances were described by Rock and King (1967) in reporting the amino acid requirements of the codling moth, Carpocapsa nomone11a Linne, using ion-exchange chromatography, with the amino acid aralyzer, and isotope labeling techniques for amino acid identifications.

Some insects receive mure thäh nutritive value from the proüucts they consume. The silkworm, Bombyx mori Linne, will not feed on artificial diets lacking in the mulberry extract since this serves as a phagostimulant (Hamamura, Hayashya and Naito 1961).

A basic consideration to the nutritional investigator is the determination of optimal quantitative and qualitative requirements for the insect and the balance between them. Often identical techniques are used by both the vertebrate and invertebrate worker. A basic diet containing all the components necessary for normal growth is fed to the insect. A series of diets are offered to the test organism containing graded levels of a given component while the balance of the diet remains constant. The optimal recuirenents for any given component of the diet 
is considered to be the minimum amount that allows for normal growth

and development. Often when minimal levels of salts are included in compounded diets and offered to the test organism, rejection or suboptimal growth results. This indicates a possible interaction between the respective dietary components and the mineral salts. The final adjustments of a diet are the most difficult. This indicates the proper balance between each of the components (Gordon 1959; House 1959, 1962). The balance between the respective components of a diet is of primary importance since it relates to metabolic processes (House 1962).

Experimentation using chemically defined diets may be 1 imited in preciseness of the data due to the contamination. Axenic reaning, egg sterilization combined with sterile technique will alleviate variables of this type (Rodriguez 1966). All the necessary components of a particular diet may be known within certain 1imits; however, the large number of variables, especially in determination of nineral salt requirements, contributes to an almost infinite number of conivinations tesuliting in obscure findings. Mineral salts may contribute to the growth processes within narrow limits with excesses becoming toxic.

Previously, mineral salt determinations for insects have been neglected. In most instances only a few of the cations have been studied from the nutritional standpoint (Chaudary and Lemonde 1962, Franke1 $1959 \mathrm{~b})$. In most nutritional investigations the carbohydrates, vitamins, amino acids, or fatty acids receive the greatest attention.

Some mineral mixtures have been commercially compounded that provide the mineral requirements for insects and vertebrates as we11. Some examples are Vanderzant's sa1ts, McCollum-Davis'\#185 and Wessens sa1ts. In most cases these salts have been compounded for vertebrate nutrition; 
however, some suffice for insects.

Mineral supplements within limits of the host plant are the most desirable; however, this is difficult to achieve without analysis of the representative host materials (Beck 1956).

More recent diets for stored product insects contain high potassium and magnesium with low calcium (Medici and Taylor 1966). Dadd (1963) and Rock and King (1966) report insects share some common mineral salt requirements with vertebrates.

The object of this study is the determination of mineral requirements and some estimated toxicities for eight mineral cations for the almond noth. Mineral requirements for the almond moth are compared with several vertebrates and other insects in Table 1.

Waites and Gothilf (1969) reported minimal vitamin B requirements for the almond moth as well as a need for vitamin $\mathrm{E}$ and linoleic acid in the diet; however, fat soluble factors are considesed non-essential in insects by many nutritional investigators. Franke1 (1959a) reporited nine B vitamins as growth factors in insects. He demonstrated carnitine to be the only vitamin required by insects and not by vertebrates. High mortality was reported for the almond moth when thiamin, riboflavin, pyridoxine, calcium pantothenate, folic acid, biotin and nicotinic acid were selectively onitted from diets (Waites and Gothilf 1969). House (1962), Dadd (1963) and Franke1 and Blewett (1946b) reported needs for fatty acids in the insect diet. Earle, Slaten and Burks (1967) reported the need for fatty acids in the boll weevil. Fast (1964) has reviewed the lipid requirements for insects.

Sterols must be included in artificial diets since this component cannot be synthesized by insects (Beck and Kapada 1957; Clark and Block 
1959; Ishiis, Kaplauis and Robbins 1963). Sterol requirements can be satisfied by the inclusion of cholesterol in the diet (Dade 1963). When cholesterol was included in the diet, wheat germ oil can be replaced by polyunsaturated fatty acids (Waites and Gothilf 1969). Retarded pupation was demonstrated when cholesterol was selectively omitted from the diets (Franke1 and Blewett 1946a). Sterols act much the same as the juvenile hormone, being needed for larval growth and oogenesis (Levinson 1955, 1960, 1962). The first need for a sterol in the diet of insects was shown by Hobson (1935).

Previous to 1950 , most amino acid studies were qualitative. This was due to the lack of analytical equipment and methods. Since the development of the amino acid analyzer and the use of radioactive isotopes for tagging diet components, the problems of the nutritional investigator have been greatly lessened. Rock and King (1968) reported and threonine as indispensable for the red banded leas rollor using glucose U-1L-C as an isotope label; however, a deletion study showed a need for tryptophan in the diet. In many instances the same amino acids were found indispensable for both vertebrates and invertebrates (Rose 1938; Moore 1946; Hinton, Noyes and E.11is 1951; Rock and King 1966; Franke1 and Printy 1954; Friend et a1. 1957; Vanderzant 1958). Chirigos, Meiss and Pisano (1960) reported on growth responses of the confused flour beetle to six proteins. Earle, Walker and Burks (1966) reported amino acid composition of cotton, thus determining optimal requirements for the boll weevil. Seventeen amino acids were reported as essential for the two spotted spider mite, $\underline{T}$. urticae (Rodriguez and Hampton 1966). Seven amino acids were reported as non-dispensable 
for the saw toothed grain beetle, oryzaephylus surinamensis Linne (Davis 1965). Few amino acids were considered essential for the cockroach, Blatella germanica Linne due to synthesis by internal symbiontg (Gordon 1959). Vanderzant (1958) reported a number of dispensable amino acids must be present in the diet in order to achieve normal growth and development.

\section{Nutrition of Some Stored Product Insect,s Including the Almond Woth, Cadra caitella}

\section{Carbohydrates}

The environment of stored product pests is in many instances high in carbohydrates. A few of the more common stored product pests are Tribolium confusum, Ephestia kockniella Hubner, Ephestia elutella, Plodia interpuncte11a Walker and Cadra caute1la, all occurring in similar environments. In nutritional studies for I. Confusum (Medici and Taylor 1966) it was necessary to include sucrose in test diets at the 85 per cent level. Naylor (1963) reported the best source of carbohydrate for $\mathrm{T}$. confusum to be cornstarch, but sucrose and glucosewere shown to provide good growth (Bernard and Lemonde 1949). Franke1 and Blewett (1946a) showed that high levels of carbolydrate were not an essential dietary component for Ephestia sp. when casein was substituted in equal amounts. Growth and $\mathcal{E}$ development of the almond moth were suppressed when dextrose was replaced by cornstarch; therefore sucrose was used as a replacement (Waites and Gothilf 1969). Under natural conditions the almond moth 1 ives on foodstuff high in carbohydrate, therefore near equal amounts are included in test diets.

Amino Acids

To date, the amino acid requirements for the almond moth have not been reported. In nutritional studies with Ephestia sp. (Frankel and 
Blewett 1946b), casein was included in test diets at 50 per cent and 80 per cent levels as a protein source. In vitamin deletion tests for the almond moth, Waites and Gothilf (1969) included casein in diets at 48 per cent. Medici and Taylor (1966) reported the confused flour beetle required the same anino acids as the rat.

In test diets for the almond moth, casein was included at the 48 per cent 1eve1, except where amino acid determinations were concerned. Basic amino acid determinations were conducted in order to develop a control diet for mineral salt determinations. A sumary of the tests is shown in Table 4. Lipids and Sterols

Franke1 and Blewett (1946c) showed a need for polyunsaturated fatty acids in the diet of several Ephestia sp. Wing deformation in the adults was observed when this component was omitted from diets. Insects cannot synthesize sterols, therefore they must be included in artificial diets.

Cholesterol acetate is included in diets at 1 y/100 9 ury diet. The acetate form of cholesterol is preferred due to its water solubility. Fat soluble components have been regarded as non-essential for insects; however, a need was shown in the almond moth for saturated fatty acids (Waites and Gothilf 1969). Wheat germ oil was included in test diets at $1 \mathrm{~g} / 100 \mathrm{~g}$ dry diet. Alpha tocopherol (vitamin E) did not show any advantage over wheat germ oil. It was suspected that alpha tocopherol was broken down to an ester at incubation temperatures. Minerals

Mineral salt requirements have been defined for few stored product insects. Medici and Taylor (1966) reported on the mineral composition of whole body tissue and dietary requirements for the confused flour 
beetle. A commercia11y compounded mixture (IfCCollum-Davis \#185') was used as a mineral source by Waites and Gothilf (1969) for nutrition of the almond moth. The same mixture was used by Frankel and Blewett (1946a) as a mineral source for Eplestia sp., a closely related group. Minera1 requirements for the rice moth Coreyra cephelonica Staint were reported by Thorsteinson (1960).

The use of atomic absorption spectrophotometry has provided useful clues to the mineral requirements of insects by analysis of whole body tissues for mineral composition. Procedures for analys is of biological tissue using atomic absorption spectroscopyare reported by willis (1965); Chang, Grover and Harrison (1966); Chang and Knox (1967); Zangg and Knox (1967); Feldman and Knoblock (1967); Elwe1l and Gidley (1962). Vitamins

A need for thiamin, riboflavin, pyridoxire, calcium pantothenate, folic acid, biotin and nicotinic acid is demonstrated for the almond moth. Wo significant uifferences were observed when p-aminobenzoic acid, choline, inositol and vitamin B-12 were selectively omitted from tests (Waites and Gothilf 1969). The vitamin mixtures used in control and test diets are shown in Table 2. Water

The almond moth norma11y 1 ives in an environment 1ow in moisture; water conservation is of the utmost importance. In the standard laboratory rearing medium, glycerine was included as a hygroscopic agent. In test diets, water was included at the rate of $12 \mathrm{ml}$ per 100 grams dry diet. This source plus metabolic water and a high relative humidity in the rearing facility satisfy the water requirements of the almond moth. 
CHAPTER III

\section{MATERTALS AND METHODS}

\section{Almond Moth Colonies}

Almond noths were reared in wide mouth half-gallon jars containing a stock rearing mediun of the following ingredients (in parts): whole wheat flour, 4; Purina dog food (fine ground), 2; brewers yeast, 1; oatmea1, 1; wheat germ, 0.5; honey, 1 and glycerine, 1 . A11 components were mixed thoroughly before being placed in jars. A shell vial $25 \mathrm{x}$ $95 \mathrm{~m}$ filled with cellu-cotton and moistened with $10 \mathrm{~m} 1$ of water was adder. A high relative humidity within the jars improves egg laying (Strong et a1. 1968). Jars are half filled with the rearing medium, the mouths covered with $9 \mathrm{~cm}$ circles of filter paper (No. 1) and sealed with netal jar rings (Figure 1). Filter paper allows for gas exchange and contains the moths. The rearing room was maintained at $80 \pm 2^{\circ} \mathrm{F}$ and $55 \pm 5 \%$ relative humidity. A minimum of six jars was selected from the stock culture for inoculating new jars to minimize the effects of interbreeding. Eggs are deposited directly on the medium. First instar larvae hatch within six days and begin to feed. Pupae were collected by inserting rolls of corrugated cardboard (19 $\mathrm{cm}$ dia) in the jars. Fourth instar larvae pupate in the corrugations and may be collected by separating the layer of cardboard. Eggs were collected after removing the pupation rolls and replacing the filter paper cover with a $9 \mathrm{~mm}$ circle of screen wire. The jars were inverted 
on a rack over petri dishes to collect the eggs (Figure 2).

Eggs, body parts, medium and frass collect in the petri dishes. Foreign matter must be separated from the opaque eggs by first filtering the material through two layers of 40 mesh wire gauze and washing several times with distilled water, each time allowing the debris to float off. The eggs were allowed to settle to the bottom of the container before being drawn into a medicine dropper and spread on strips of No. 1 filter paper. The strips were placed in $25 \mathrm{~m} 1 \mathrm{via} 1 \mathrm{~s}$ and plugged with non-absorbent cotton. Incubation was accomplished in a Hotpack Refrigerated Incubator at $80 \pm 2^{\circ} \mathrm{F}$ and $80 \%$ relative hunidity.

Casperi (1941) reported the influences of low temperatures on the population of E. kuehnie11a, a closely related species and found egg production to be reduced significant $1 \mathrm{y}$ at $10 \mathrm{w}$ temperatures and relative humidities.

Newly hatched larvae were removed from the vials by removing the cotton plug and tapping the base of the inverted vial over a dark nonporous surface. Only those larvae that moved away from the mass are selected for testing. Larvae handling is accomplished by picking up the larvae, one by one, with a modified No. 1 camel's hair brush.

Four days before each experiment, several hundred eggs were collected and separated from the foreign matter. When the experiment was started, newly hatched larvae were selected and placed in she11 vials with the test diets. Each test consisted of 10 replicates plus a control. All vials were enclosed in pint ice cream cartons and incubated at $80 \pm 2^{\circ} \mathrm{F}$ and $80 \%$ relative humidity. The acceptance of test diets was evident within 5-7 days. As larvae feed, tunneiing and frass become eviaent throughout the medium. 
In earlier experinents a control diet of crude ingredients was used. A control diet of a more exact composition was adopted from the all vitamin diet shown in Table 2. A diet of this type, rather than the crude one proved more compatibie with the tests being conducted. Statistical analyses show that the use of a control in each experiment is advisable.

In near1y every test, the control diet required fewer days for larval development than test diets. The control was arrived at in the preliminary amino acid determinations. This diet was used as the control for all investigations conducted here.

\section{Atomic Absorption Spectrophotometric Analys is}

Larvae, pupae, adults and random samples of the standard laboratory rearing medium were analyzed for mineral salt content using a Varian mode1 100 Atomic Absorption Spectrophotometer (Figures 3 and 4).

All test organisms were collected from the laboratory colony. Each test samplo was dried in a Boekel drying oven at $150^{\circ} \mathrm{C}$ for 12 hours before ashing. The ashing process was intended to oxidize all components of the sample except mineral salts. This was done in a Boekel muffle furnace at $500^{\circ} \mathrm{C}$ for 15 hours (Figure 5). Samples to be ashed were weighed and placed in covered $50 \mathrm{ml}$ crucibles before being placed in the muffle furnace. A minimum of $10 \mathrm{grams}$, wet weight, was used. The furnace was heated at a gradual rate to avoid spattering of the samples. If, after ashing the sample for 15 hours, a brown or black residue persisted, 1-3 $\mathrm{ml}$ of $2 \mathrm{M} \mathrm{HNO}-3$ was added and was reheated at $500^{\circ} \mathrm{C}$ for two hours. If the residue persisted, then it was regarded as sulfide and treated as such.

Upon completion of the ashing process, samples were again weighed 
and dissolved in 5-10 $\mathrm{ml} 1 \mathrm{~N} \mathrm{HC1}$. Usual1y 5-10 $\mathrm{mg}$ of ash were necessary for each determination. For each of the mineral salts, a standard curve was plotted on logarithmic paper. Parts per million per gram of. ash was determined by plotting a standard curve. For each determination, a standard solution of known concentration was included. This served as a check and a basis on which to determine the concentration of the unknown. The following equation was used to compute the concentration

$$
\mathrm{PPM} / \mathrm{g} \text { ash }=(\text { PPM } \times 10) \times \frac{1}{\text { wt of ash }}
$$

Mineral determinations were made for the following cations: potassium, magnesium, sodium, calcium, iron, zinc, manganese and copjer. Sodium, potassium, calcium and manganese werediluted to a 1-500 dilution, since there were $20-30 \mathrm{mg}$ of ash per total volume. Zinc was diluted to a 1-25 dilution and copper was not diluted. Dilutions are necessary since some of the salt occurs in higher concentrations than others, tius causing excessive absorbance for the particular cation. In some cases, high level salts were determined using a small portion of the aqueous flame, thus serving the same purpose as dilution.

This procedure for analysis is relatively new and utilizes a significant approach to determination by means of atomic spectra. Developed by the Division of Chemical Physics, Melborne, Australia, this method allows for the determination of small amounts of one element in the presence of high concentrations of other elements. In addition, many metals such as zinc and magnesium, which are difficult to determine by other means, can be detected with a high degree of sensitivity.

Experimental Diet Preparation

The composition of a11 control diets used is shown in Table 2. The mineral mixture was modified from Medici and Taylor (1966). The 
vitamins were those reported by Waites and Gothilf (1969).

The control and test. diets were prepared by thoroughly grinding all basic components including sucrose and casein in a mortar with a pestle. This was done to attain unifornity in particle size which might. be indistinguishable to the feeding larvae (all vitamins and minerals were reagent grade). The mineral mixture was included with the vitamin solution and mixed thoroughly into the diet. The components that were added in solution are those which are present in small amounts. Wheat germ oil was dissolved in 5-10 $\mathrm{ml}$ ethyl ether and mixed into the diet until a11 traces of ether disappeared. Cholesterol acetate was added directly to the diet. The diet was thinly spread on paper and refrigerated overnight. Before use, the diet was again ground in a mortar with a pestle. Approximately $1.5 \mathrm{~g}$ of test diet was used for each test. Tests were conducted in shel1 vials $15 \times 75 \mathrm{~mm}$ which were plugged with non-absorbent cotton. Ten replicates were run for each treatment. Newly hatched first instar larvae were transferred to test diets. All test and control vials were placed in pint ice cream cartons and incubated in a Hotpack Refrigerated Incubator at $80 \pm 2^{\circ} \mathrm{F}$ and $80 \%$ relative humidity. All diets were used within two days after preparation; however, control diets were sometimes prepared and stored under refrigeration.

\section{Statistical Analysis}

Experiments analyzed were not designed with any particular type of statistical treatment in mind; however, the nature of the results required that a test be applied that would compare the means of each treatment having different sample sizes. Analysis of variance was run at the 1 per cent level of significance. The Duncan multiple range test (Steel and Torrie 1960) was selected for the final analysis. 
For each treatment, the multiple range test was applied which included data from the control diet, that is the largest average minus the smallest, which in most instances was the control.

The difference between developmental time requirements for larvae reared on test diets and control diets is important, therefore the least significant difference at the 1 per cent level was determined. Only those data from test diets and control diets that were run simultaneously were compared. This test showed if one treatment within a given response was more signiricant than another.

Larval Growth Analysis

Criteria for evaluating the effects of each diet were similar to those used by Waites and Gothilf (1969), that is, the number of larvae surviving to pupation and the average time required to reach the pupal stage. When diets showed favorable responses, an analysis of variance was run to determine the differences in treatments. When response was good for a series of treatments, these were compared statistically using a multiple range test developed to rank the treatment means as they became known. This is in direct contrast to individual degrees of freedom and least significant difference where the hypothesis is formulated before the treatment means are known. 


\section{CHAPTER IV}

\section{PROCEDURAI, PROBLEMS}

\section{Mites}

Periodic infestation of the rearing room with mites presented a threat to the almond moth colony. The mites were determined to be of the family Orbatiidae. This group of mites is a common pest of stored products throughout the wor1d. A survey of insects and mites associated with stored products was reported by Champ (1966). Once established, mites thrive on the energy rich nedium provided for almond moth rearing. A threat to the colony exists when the mite population reaches a level sufficient to crowd out the larvae of the almond moth. The crowding effect is in the form of competition for available food. The stored product mite reproduces in large numbers and has a relatively short life cycle.

Control of the mite infestation was difficult. Initial control measures were to remove infested jars from the colony; however, this did not prove effective. Limited control was accomplished by heating the components of the standard rearing medium at $150^{\circ} \mathrm{C}$ for two hours before use; however, token infestation persisted. Final control was brought about by fumigating the rearing room with vapona. This compound was supplied by the Shell Chemical Company in the form of a resin strip impregnated with 2, 2-dichlorovinyl dimethyl phosphate. After removing the resin strip, Mexican bean beetles were placed in the 
facility to test the residual effect. Toxic levels were present up to 72 hours after treatment, and subsided oniy after the relative humidity was increased to approxomately $95^{\prime}$ per cent.

As an adcled precaution against future mite infestation, al1 components of the standard laboratory rearing nedium were routinely heated to $150^{\circ} \mathrm{C}$ for two hours before use. Eggs used for inoculating medium and test diets were washed in distilled water and routine inspection of the almond moth colony was conducted to avoid build up of mites. It was suspected that the mite may become phoretic on the almond moth during part of its life, therefore contributing to dispersion of mites throughout the laboratory colony.

\section{Microbial Contamination}

The standard laboratory rearing medium, control diets and test diets are high in carbohydrates and relatively dry, therefore not conducive to bacterial growth. A need for a diet component to control microbial growth was not necessary. Steinhaus and Be11 (1953), Medici and Taylor (1966) reported on antibiotics and their effect on artificial diets for stored product insects. The need for antibacterial components is more pronounced in liquid diets (Rodriguez. i966).

Larval Handling

One of the basic problems conflonting the insect nutritional investigator is development of an efficient method to randle the test organism. First instar larvae of the almond moth were transferred using a modified No. 1 camel's hair brush; other instars were handled using soft touch forceps. Moths were collected in mass by knocking them down with $\mathrm{CO}-2$ or low levels of ethyl acetate and picking them up with soft touch forceps or by aspirator. 
Beet1e Infestation

The confused flour beetle, $\underline{T}$. confusum, may be found in comercialiy purchased flour and meal. Control is accomplished by heating these components at $150^{\circ} \mathrm{C}$ for two hours before use. 


\section{CHAPTER V}

\section{EXPERINENTAL}

\section{Preliminary Investigations}

Al1 investigations covered here contributed to the final determination of mineral salt requirements for the almond moth. Vitamins, Cholesterol and Fat

Vitamins used in the control diet and the test diets were the same as those used by Waites and Gothilf (1969).

Wheat germ oil was included in the diet in the amounts shown in Table 2 for the control and experimental diets. The unsaponifiable portion of wheat germ oil contains large amounts of vitamin E (alpha tocophero1) but this is not known to satisfy the sterol requirement for the almond moth (Frankel and Blewett 1946c). Previous to this, fatty acids were considered non-essential for insect diets; however, it was found that Ephestia sp. emerged with deformed wings when this component was omitted from diets (Frankel and Blewett 1946b). Fatty acids in the diet seemed to give the components a measure of consistency. Waites and Gothilf (1969) reported that wheat germ oil could be replaced with unsaturated fatty acids when cholesterol was present in the diet. Cholesterol seems to satisfy the sterol requirement in the diet thus influencing pupation (Frankel and Blewett 1946a). Amino Acid Studies

Some preliminary investigations were made on the amino acid re- 
quirements for the almond moth. Thirteen amino acids were tested at. graded levels as shown in Tables 3 and 4 . The number of surviving larvae and days required to reach pupation were used as criteria for evaluation of test diets. In a11 tests, a control diet of three replicates using caseir as the amino acid source was used. Each treatment mean was compared statislicaliy to the control mean.

In these tests, a deletion series similar to the model for mineral salt determinations was used. Levels of amino acids per replicate ranged from 0.0 to 1.5 grams per 100 grams of dry diet. Analysis of variance was run for each set of means. The significance was tested at the one per cent level. The levels underlined in Table 3 statistically proved to be optimal.

This experiment was not intended to be conclusive for the anino acid requirements; however, in most cases the optimal levels for each amino acid were relatively distinct. It is difficult to state the amino acid requirements closer than to the nearest tenth of a per cent of that diet; thus a standard error of $\pm 15 \%$. Closer determinations would serve this investigation no useful purpose since the amino acid requirements change with the protein quality of respective diets. The minimal levels for amino acids reported here were considered by this worker to be suboptimal for the almond moth since growth was not as good as that demonstrated by the control diet.

\section{Carbohydrates}

Several sources of carbohydrates were used in preliminary investigations. Waites and Gothilf (1969) selected sucrose over dextrose due to the darkening of the latter after heat sterilization. For this study sucrose was chosen as the carbohydrate source. 
Minera1 Studies

In the mineral salt determinations, it, was necessary to use a salt mixture of a more exact composition rather than the crude wheat germ used in the stock rearing mediun or the commercially compounded mixtures as provided for vertebrate nutrition. This was essential if optimal levels for each cation wele to be deiermined. Earlier preliminary investigations involved such commercially prepared salt mixtures as Vanderzant's sa1ts (Nutritiona1 Biochemicals Co.), Medicis and Taylor's mineral mixture (1966), McCol1un-Davis' mixture No. 185 (Jones and Foster 1942) and Beck et a1. (1968)mixture. Of these compositions a modification of Beck et a1. (1968) proved superior for the almond moth. The McCollum-Davis mixture No. 185 was designed primarily for vertebrate nutrition, whereas Medici's and Vanderzant's were formulated for insect nutrition. Calcium requirements for vertebrates are understandably higher due to the nature of the skeleton. The insect exoskeleton does not require high levels of calcium; however, calcium is required for such phenomena as nerve impulse transmission, membrane permeability and nerve endplate intervention (Patton 1963). Calcium is present in fourth instar larvae of the almond moth at about 0.3 percent (Table 5).

Spectrophotometric determinations for eight mineral sa1t cations in growth stages of the almond moth are given in Table 5. This analysis was conducted as a basis for deletion studies to determine optimal mineral salt requirements in an artificial diet. Similar determinations for the components of the standard laboratory learing medium are shown in Table 6.

Nutrients norma11y consumed by stored product insects are high in 
potassium and magnesium and low in calcium and sodium Medici and Taylor 1966). The optimal levels of each of the salts might be expected to parallel those of the natural foodstuffs; however, this did not prove to be true for the almond moth. In one of the few successful mineral investigations for insects, Beck et al. (1968) used a supplement of nine mineral salts. On the basis of this mineral mixture, a control diet was tested at $.5,1.0,1.5$ and 2.5 per cent levels for their effect on growth and development of almond moth larvae. The supplement contained all the cations present in Beck's et a1. (1968) mixture plus high levels of manganese and magnesium. The best of the supplements proved to be those low in sodium, zinc and calcium and high in magnesium. Tests of ten replicates were conducted for each level. Controls using standard laboratory rearing medium were included. Best growth was demonstrated at the one per cent leve1, and therefore chosen for the control diet for minerals and amino acids (Table 2).

The minimal level fur eight mineral salts are shown in Table 7 . In each determination there were levels found toxic or growth retarding. The minimal requirements and the relative estimated toxicities for each are shown in Table 9.

Dadd (1960) reported a need for dietary bulk in some insects. He theorized that larval growth might be improved if inert materials were present; however, tests with Alphacel at 20 per cent, 30 per cent and 50 per cent levels showed no significant improvement; therefore the need for a bulk component was considered unnecessary for normal growth and development of the almond moth.

Composition of the minerals supplied by the mineral control diet and the amount of cations supplied by each salt are shown in Table 8 . 


\section{CHAPTER VI}

\section{RESULTS AND DISCUSSION}

Deletion studies for amino acjd requirements in the almond moth showed a need for many of the same ones considered indispensable in the rat and other stored product insects. Studies of this type do not indicate which, if any of the amino acids are synthesized in vivo.

Quantitative and qualitative data using labeled compounds to determine amino acid synthesis in the almond moth would be helpful. Definite similarities may exist between composition of whole body tissue and the pattern of amino acids required in the diet. Prelininary investigations showed a need in the almond moth for the following amino acids: (pen cent of total diet) phenylalanine 1.0; 1ysine 1.0; leucine 0.7; arginine 0.6 ; histidine 0.5; isoleucine 0.5 ; glutamic acid 0.5 ; valine 0.4 ; threonine 0.3; tryptophan 0.2 and cystine at 0.1 .

Reduced growth was observed when arginine, lysine, phenylalanine and leucine were selectively omitted from test diets. The need for cystine and tryptophan was indistinct as were methionine and glycine but to a lesser degree. Synthesis of amino acids may supplement many of those supplied in the diet. A need for histidine was suspected since it is considered indispensable in many stored product insects. A distinct need was shown for isoleucine, glutamic acid, valine, glycine and threonine in the diet of the almond moth (Tables 3 and 4 ). 
Al1 insects studied to date have been fed ad 1 ibitur when tested for amino acid requirements. The differences in requirements may be due to different feeding rates, metabolic rates and times to pupation. Comparing some insects in relative order of size, the almond moth is the smallest, followed by the pink bollworm, the codling moth and the honey bee (the largest). The time to pupation is shortest for the smallest insect, and longest for the largest. The metabolic rates of most insects are not known, but it may be expected that the smaller the insect the higher the metabolic rate. Thus, higher netabolic rates are necessary for smaller individuals in order to supply more heat and metabolic moisture per unit hody weight. Relatively speaking, the smallest insects require the lower percentages of amino acids in the diet, and the larger require the higher percentages. This is possibly due to the relative feeding rates rather than the actual requirements. Tests of ten replicates showed the predetermined optimal levels of anino acids (Tables 3 and 4) to be wanting when compounded into whole diets. Final adjustments of amino acids were indicated. Since these amino acid levels did not prove satisfactory, casein was included in the control and test diets as the amino acid source.

A deletion study similar to that conducted for the B vitamins (Waites and Gothilf 1969) was conducted for eight minerals considered essential for life processes in insects. The first consideration to this investigation was the determination of optimal mineral levels in the diet of the almond moth. As a basis for quantitative estimations of mineral levels required in test diets, data from spectrophotometric analysis of whole bodies of the almond moth developmental stages were considered (Table 5). These data were included in deletion studies to 
determine if a relationship existed between minera1 concentrations in body tissue and dietary requirements (Table 7). This study did not indicate such a relationship. It was concluded that the mineral levels present in whole body tissue were derived from prolonged assimilat ion of body tissues over the entire developnental period and do not indicate optirial mineral levels for nutritional purposes.

The mineral levels underlined in Table 7 were compounded into whole diets and fed to first instar larvae of the almond moth. Tests of ten replicates demonstrated total rejection within 3-6 hours and larval death after 8 hours. Dehydration was indicated as the causative factor.

Additional water did not reduce the mortality of larvae placed on this diet. Tests indicated a high mortality when total mineral concentration exceeded 3 per cent. Experimental evidence showed lower levels of magnesium, potassium and zinc to improve survival.

In the diet of the confused flour beetle extra $z$ inc reduced the toxic levels of cadmium, and extra copper slightly reduced the toxic levels of zinc and cadnium. Although cadmium was not considered in these tests, there were certain interrelationships between cations in diets that when applied to metabolic processes of insects could prove interesting.

High mortality was observed when potassium, magnesium or zinc exceeded $.350, .125$ and $.001 \mathrm{mg} / 100$ grams of dry diet respective1y. High levels of calcium are needed in diets; however, high sodium levels compensate for a calcium difficiency. Sodium is necessary in artificial diets; however, the need was difficult to demonstrate by deletion studies since these cations occur in high amounts in the unsupplemented diet. 
This was also true for copper, but to a lesser degree. A need for copper and sodium is common among insects. No relationship was shown between any of the toxic levels and nutritional requirements for the almond moth (Table 9).

Tests indicated that dietary levels of magnesium need not be as high when potassium is increased proportionately. This may indicate a sharing of some common anions necessary for enzymatic thresholds.

the need for iron was not indicated although reduced growth resulted when iron fell below $.01 \mathrm{mg} / 100$ grams dry diet. Insects do not require a ferrous hemoglobin for oxygen transport in the blood as do vertebrates. No response was shown when manganese was increased or deleted in test diets. Tests of ten replicates per graded mineral level showed the following mineral levels to be optinal: (mg/100 mg dry diet) potassium .325; ca1cium 1.0; sodium .002; iron .01; zinc .0001; magnesium .100 and copper .005 . Mineral requirements for insects differ greatly within the developmental stages of the same species.

Habitat, feeding habits, internal symbionts and other factors play important roles in nutritional requirements which are more varied than the types of insects themselves. Mineral salt requirements vary greatly within the order Insecta, and findings are often vague and inconclusive. Precise methodology is essential for accurate mineral salt determinations. Aseptic laboratory technique is important if accurate determinations are to be made. Contamination of test samples often introduces foreign cations into analysis and obscures final calculations and conclusions. The almond moth has proven to be an excellent assay organism for nutritional studies. Its ease in rearing and relatively short life cycle provide large numbers of test organisms in a short period of time. 
The standard 1aboratory rearing medium and the test diets are low in moisture, therefore not subject to microbial contanination. Almond moth larvae respond we11 to dietary and environmental changes, and the species is readily avaijable in nature. All developmental stages were hardy and resistant to experimental stresses during the course of study. 


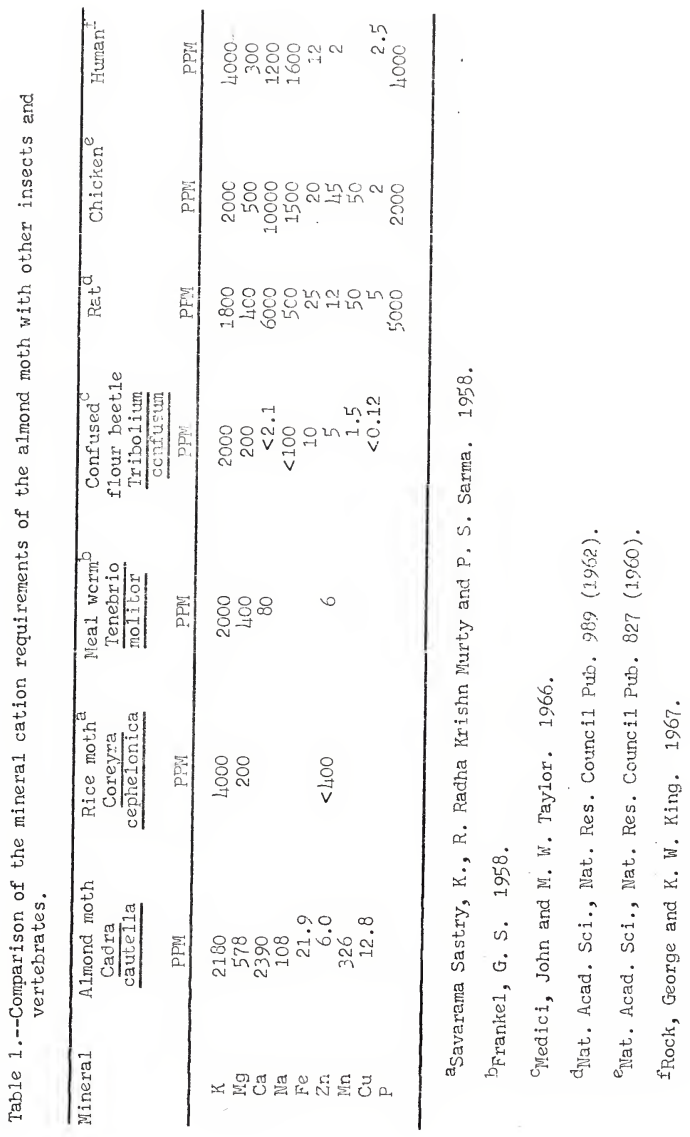


Table 2.--Basic diet for nutritional work with the almond moth (modification of Franke1 and Blewett (1946a) a11 vitanin diet and Beck, Chippendale and Swinton (1968) salt mixiure).

\begin{tabular}{lc}
\hline & $\mathrm{g} / 100 \mathrm{~g}$ dry diet \\
Casein & 48.0 \\
Sucrose & 48.0 \\
Salt Mixture & .73 \\
Cholestero1 & 1.0 \\
Wheat Germ Oil & 1.0 \\
Vitamin Solution & $12 \mathrm{~m} 1$ \\
\hline
\end{tabular}

$\mathrm{mg} / \mathrm{g}$ dry diet

Thiamin Hc1

Riboflavin

50.0

Nicotinic Acid

50.0

Pyridoxine Hcl

50.0

50.0

D1-Ca Pantothenate

50.0

p-Aminobenzoic Acid

50.0

i-Inositol (Meso)

500.0

Choline Chloride

500.0

Folic Acid

10.0

Biotin

Vitamin B-12

0.1

0.4

\begin{tabular}{|c|c|c|}
\hline Salts & $\begin{array}{l}\text { Salt mixture } \\
\% \\
\end{array}$ & $\begin{array}{c}\text { Larval diet } \\
\%\end{array}$ \\
\hline $\mathrm{K} 2 \mathrm{HPO} 4$ & 31.75 & 0.66 \\
\hline $\mathrm{KH} 2 \mathrm{POL}$ & 34.25 & 0.68 \\
\hline $\mathrm{MgSO}_{4}$ & 18.00 & 0.34 \\
\hline $\mathrm{Ca}(\mathrm{H} 2 \mathrm{PO} 4) 2 . \mathrm{H} 2 \mathrm{O}$ & 6.00 & 0.14 \\
\hline $\mathrm{NaCl}$ & 6.00 & 0.10 \\
\hline $\mathrm{Fe} 2\left(\mathrm{SO}_{4}\right) 3.6 \mathrm{H} 2 \mathrm{O}$ & 3.00 & 0.05 \\
\hline $\mathrm{MnSO} 4 \cdot \mathrm{H} 2 \mathrm{O}$ & 0.40 & 0.01 \\
\hline $\mathrm{Zn}()) \mathrm{CCH} 3) 2.2 \mathrm{H} 2 \mathrm{O}$ & 0.40 & 0.01 \\
\hline CuSO $4.5 \mathrm{H} 2 \mathrm{O}$ & 0.25 & 0.004 \\
\hline
\end{tabular}


Table 3.--Growth of the almond moth on graded levels of amino acids (minimal requirements underlined).

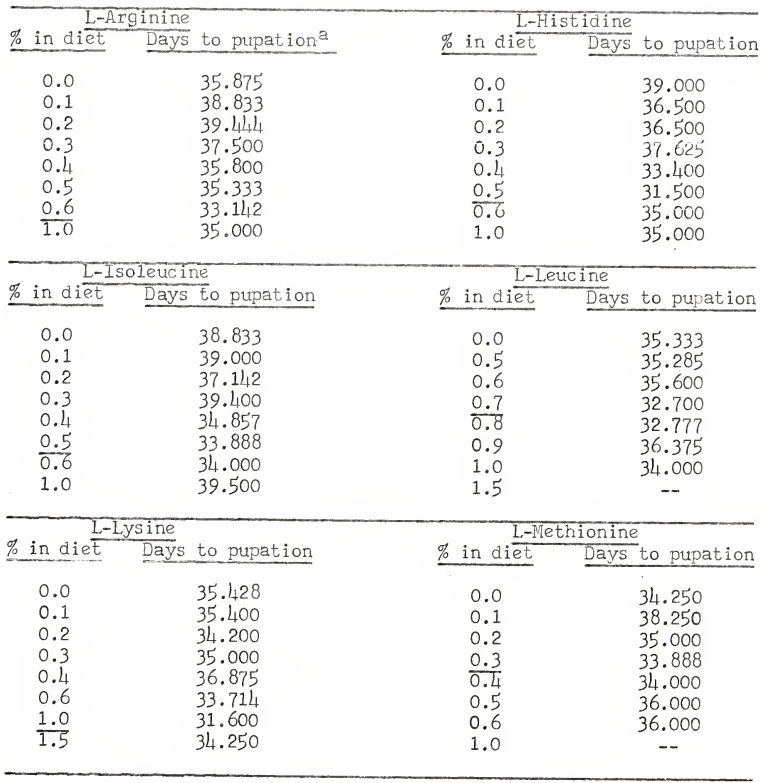

a Days to pupation are the average number of days required to reach pupation for ten vials for each graded level. 
Table 3 Continued

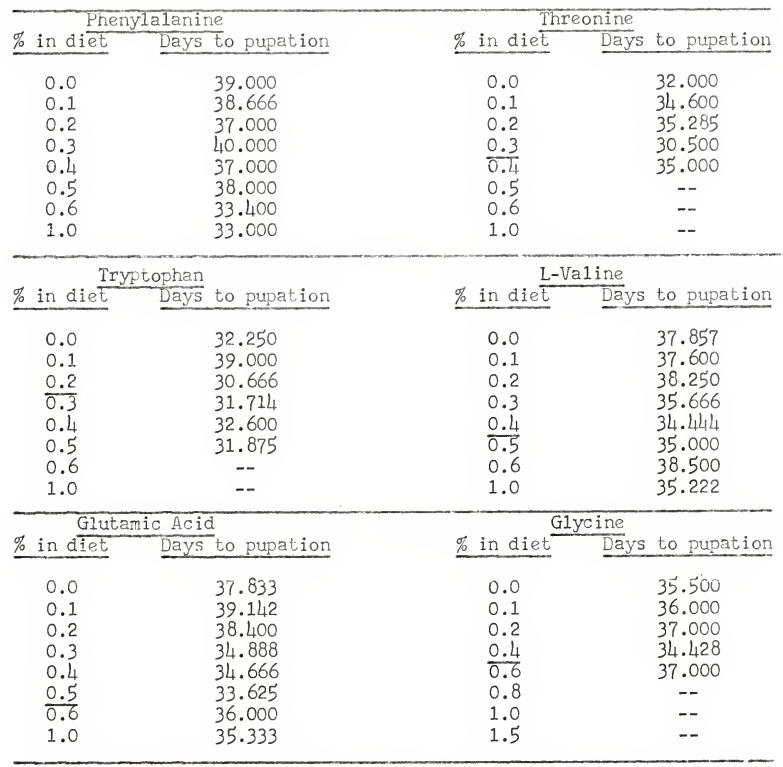

L-Cystine

$\%$ in diet Days to pupation
0.0
40.375
0.1
33.833
0.2
39.444
0.3
0.4
0.5
0.6
1.0
34.000
35.000
36.400
37.00
35.250 

Table 4.--Sumary of the amino acid deletion series (minimal levels
underlined).

\begin{tabular}{|c|c|c|c|c|c|c|c|c|}
\hline \multirow{3}{*}{$\%$} & \multicolumn{8}{|c|}{$\mathrm{ng} / 100 \mathrm{~g}$ dry diet } \\
\hline & & & & eatrier & & & & \\
\hline & 1 & 2 & 3 & 4 & 5 & 6 & 7 & 8 \\
\hline L-arginine & 0.0 & 0.1 & 0.2 & 0.3 & 0.4 & 0.5 & $\underline{0.6}$ & 1.0 \\
\hline L-histidine & 0.0 & 0.1 & 0.2 & 0.3 & 0.4 & 0.5 & 0.6 & 1.0 \\
\hline L-isoleucine & 0.0 & 0.1 & 0.2 & 0.3 & 0.4 & $\underline{0.5}$ & 0.6 & 1.0 \\
\hline L-1eucine & 0.0 & 0.5 & 0.6 & 0.7 & 0.8 & 0.9 & 1.0 & 1.5 \\
\hline L-1ysine & 0.0 & 0.1 & 0.2 & 0.3 & 0.4 & 0.6 & 1.0 & 1.5 \\
\hline L-methionine & 0.0 & 0.1 & 0.2 & 0.3 & 0.4 & 0.5 & 0.8 & 1.0 \\
\hline L-phenylalanine & 0.0 & 0.1 & 0.2 & 0.3 & 0.4 & 0.5 & 0.6 & $\underline{1.0}$ \\
\hline L-threonine & 0.0 & 0.1 & 0.2 & 0.3 & 0.4 & 0.5 & 0.6 & 1.0 \\
\hline L-tryptophan & 0.0 & 0.1 & 0.2 & 0.3 & 0.4 & 0.5 & 0.6 & 1.0 \\
\hline L-valine & 0.0 & 0.1 & 0.2 & 0.3 & 0.4 & 0.5 & 0.6 & 1.0 \\
\hline L-glutamic acid & 0.0 & 0.1 & 0.2 & 0.3 & 0.4 & $\underline{0.5}$ & 0.6 & 1.0 \\
\hline L-glycine & 0.0 & 0.1 & 0.2 & 0.4 & 0.6 & 0.8 & 1.0 & 1.5 \\
\hline L-cystine & 0.0 & 0.1 & 0.2 & 0.3 & 0.4 & 0.5 & 0.6 & 1.0 \\
\hline
\end{tabular}

The level was chosen on the basis of $1 \%$ level of significance with the lowest significant amount as optimal. acid.

a Each treatment represents ten replicates per graded level of anino 
Table 5.-.Mineral salt composition of the almond moth in different stages of development.

\begin{tabular}{|c|c|c|c|}
\hline & Larvae & Pupae & Moths \\
\hline Ash content $\%^{\mathrm{a}}$ & 1.51 & 1.60 & 1.60 \\
\hline Cation & \multicolumn{3}{|c|}{$\%$ cation present in ash } \\
\hline $\mathrm{K}$ & .842 & .765 & .671 \\
\hline $\mathrm{Mg}$ & .911 & .843 & .735 \\
\hline $\mathrm{Na}$ & $.96 ? 1$ & .834 & .733 \\
\hline $\mathrm{Ca}$ & .341 & .496 & .2 .46 \\
\hline Fe & .401 & .374 & $.342^{\prime}$ \\
\hline $\mathrm{Zn}$ & $.314_{4}$ & .295 & .3391 \\
\hline Mn & .050 & .012 & $.126 \mathrm{C}$ \\
\hline $\mathrm{Cu}$ & .041 & .024 & .0260 \\
\hline
\end{tabular}

aA total of $10 \mathrm{~g}$ of tissue was tested for each developmental stage by spectrophotonetric analysis. 
Table 6.--Mineral salt content of the standard laboratory rearing medium for the almond moth as determined by atomic absorption spectrophotomet ry.

\begin{tabular}{|c|c|c|c|c|c|c|}
\hline $\begin{array}{l}\text { Total ash }{ }^{a} \\
\text { content } \%\end{array}$ & $\begin{array}{l}\text { Whole } \\
\text { wheat } \\
\text { flour } \\
1.3\end{array}$ & $\begin{array}{c}\text { Brewers } \\
\text { yeast } \\
6.9\end{array}$ & $\begin{array}{c}\text { Cornnea } 1 \\
1.9\end{array}$ & $\begin{array}{c}\text { Quick } \\
\text { oats } \\
1.7\end{array}$ & $\begin{array}{c}\text { Wheat } \\
\text { germ } \\
3.2\end{array}$ & $\begin{array}{c}\text { Purina } \\
\text { dog meal } \\
2.6\end{array}$ \\
\hline Cation & $\%$ & $\%$ & $\%$ & $\%$ & $\%$ & $\%$ \\
\hline K & .865 & .963 & $.865^{\prime}$ & .986 & .842 & 1.027 \\
\hline $\mathrm{Mg}$ & .921 & .742 & .724 & .942 & .955 & .761 \\
\hline $\mathrm{Na}$ & .350 & .114 & .455 & .814 & .948 & .659 \\
\hline $\mathrm{Ca}$ & .811 & .618 & .746 & .418 & .896 & .447 \\
\hline $\mathrm{Fe}$ & .420 & .261 & .245 & .119 & .278 & .781 \\
\hline $\mathrm{Zn}$ & .216 & .376 & .191 & .126 & .243 & .492 \\
\hline $\mathrm{Mn}$ & .219 & .014 & .014 & .027 & .036 & .265 \\
\hline $\mathrm{Cu}$ & .031 & .018 & .029 & .029 & .019 & .741 \\
\hline
\end{tabular}

a 10 gram samples of each component were analyzed. 
Table 7.--Growth of the almond moth on diets with graded mineral levels.

\begin{tabular}{|c|c|c|}
\hline \multicolumn{3}{|c|}{ Copper } \\
\hline$\frac{\text { CuSOL. }}{\%}$ & $\begin{array}{l}\mathrm{Cu} \\
\text { PPY }\end{array}$ & Days to pupation ${ }^{b}$ \\
\hline $\begin{array}{l}0.0 \\
0.0001 \\
0.0005 \\
0.001 \\
0.002 \\
0.005 \\
0.02 \\
0.10 \\
0.20 \\
0.50 \\
1.00\end{array}$ & $\begin{array}{c}.12^{\mathrm{a}} \\
.37 \\
1.39 \\
2.66 \\
5.20 \\
12.8 \\
50.9 \\
254.0 \\
508.0 \\
1270.0 \\
2540.0\end{array}$ & $\begin{array}{l}35.142 \\
33.375 \\
36.333 \\
33.625 \\
35.800 \\
33.200 \\
38.750 \\
-- \\
-- \\
-- \\
--\end{array}$ \\
\hline \multicolumn{3}{|c|}{ Potassium } \\
\hline$\frac{\mathrm{KH} 2 \mathrm{PO} 4}{\%}$ & $\stackrel{\mathrm{K}}{\mathrm{PP}}$ & Days to pupation \\
\hline $\begin{array}{l}0.00 \\
0.01 \\
0.10 \\
0.30 \\
0.50 \\
0.75 \\
1.00 \\
1.40 \\
2.00 \\
4.00\end{array}$ & $\begin{array}{r}28.3 \\
57.0 \\
315.0 \\
889.0 \\
1470.0 \\
2180.0 \\
2900.0 \\
3936.0 \\
5770.0 \\
14200.0\end{array}$ & $\begin{array}{l}33.428 \\
33.833 \\
32.800 \\
34.142 \\
29.750 \\
29.375 \\
31.100 \\
33.300 \\
34.250 \\
35.600\end{array}$ \\
\hline
\end{tabular}

amount of salt present in unsupplemented diet.

bMean of 10 replicates. 
Table 7 Continued

\begin{tabular}{|c|c|c|}
\hline \multicolumn{3}{|c|}{ Sodiun } \\
\hline$\frac{\mathrm{NaC1}}{\%}$ & $\frac{\mathrm{Na}}{\mathrm{PPM}}$ & Days to pupation \\
\hline $\begin{array}{l}0.00 \\
0.0001 \\
0.0005 \\
0.002 \\
0.01 \\
0.10 \\
1.00 \\
3.00 \\
10.00\end{array}$ & $\begin{array}{r}100.0 \\
100.0 \\
102.0 \\
108.0 \\
139.0 \\
493.0 \\
4030.0 \\
11800.0 \\
39400.0\end{array}$ & $\begin{array}{c}39.000 \\
33.500 \\
34.714 \\
29.500 \\
35.571 \\
35.500 \\
-- \\
-- \\
--\end{array}$ \\
\hline$\frac{\mathrm{Ca}\left(\mathrm{H}_{2} \mathrm{PO} \mathrm{L}_{4}\right) 2 . \mathrm{H} 2 \mathrm{O}}{\%}$ & $\frac{\text { Calcium }}{\frac{\mathrm{Ca}}{\mathrm{PPV}}}$ & Days to pupation \\
\hline $\begin{array}{l}0.00 \\
0.0001 \\
0.0005 \\
0.002 \\
0.010 \\
0.160 \\
1.500 \\
\frac{1.000}{10.000}\end{array}$ & $\begin{array}{r}2.1 \\
3.2 \\
2.9 \\
5.3 \\
18.0 \\
257.0 \\
2390.0 \\
6380.0 \\
15900.0\end{array}$ & $\begin{array}{l}35.714 \\
36.166 \\
35.142 \\
36.142 \\
33.600 \\
32.625 \\
31.000 \\
35.800 \\
35.375\end{array}$ \\
\hline$\frac{\text { FeSO } 4.7 \mathrm{H} 2 \mathrm{O}}{\%}$ & $\frac{\text { Iron }}{\text { PE }}$ & Days to pupation \\
\hline $\begin{array}{l}0.00 \\
0.0001 \\
0.001 \\
0.005 \\
0.010 \\
0.04 \\
0.10 \\
0.50 \\
1.00\end{array}$ & $\begin{array}{r}1.8 \\
2.0 \\
3.8 \\
11.9 \\
21.9 \\
82.2 \\
203.0 \\
1107.0 \\
2010.0\end{array}$ & $\begin{array}{c}33.333 \\
34.285 \\
39.000 \\
34.875 \\
33.200 \\
34.750 \\
-- \\
-- \\
--\end{array}$ \\
\hline
\end{tabular}


Table 7 Continued

\begin{tabular}{|c|c|c|}
\hline \multicolumn{3}{|c|}{ Magnesium } \\
\hline$\frac{\mathrm{MgSO} 4}{\%}$ & $\frac{M g}{P \bar{M}}$ & Days to pupation \\
\hline $\begin{array}{r}0.000 \\
0.010 \\
0.100 \\
0.200 \\
0.250 \\
0.320 \\
1.000 \\
2.000 \\
5.000 \\
10.000\end{array}$ & $\begin{array}{r}73.0 \\
93.0 \\
275.0 \\
477.0 \\
578.0 \\
719.0 \\
2090.0 \\
4110.0 \\
10200.0 \\
20300.0\end{array}$ & $\begin{array}{l}33.000 \\
35.571 \\
35.750 \\
34.000 \\
32.500 \\
36.000 \\
35.333 \\
35.833 \\
34.000 \\
34.833\end{array}$ \\
\hline$\frac{\mathrm{ZnC} 12}{\%}$ & $\frac{Z \text { inc }}{\frac{Z n}{P P M}}$ & Days to pupation \\
\hline $\begin{array}{l}0.00 \\
0.0001 \\
0.0005 \\
0.001 \\
0.005 \\
0.010 \\
0.02 \\
0.10 \\
1.00\end{array}$ & $\begin{array}{r}1.2 \\
1.7 \\
3.6 \\
6.0 \\
25.2 \\
49.2 \\
97.2 \\
481.0 \\
4810.0\end{array}$ & $\begin{array}{c}34.500 \\
37.000 \\
35.000 \\
32.333 \\
32.500 \\
34.857 \\
33.250 \\
---\end{array}$ \\
\hline
\end{tabular}

\section{MnSOL.H2O}

Manganese

$\%$ PPM Days to pupation

\begin{tabular}{lrl}
\hline 0.0 & 1.2 & 34.777 \\
0.0001 & 1.5 & 36.200 \\
0.0005 & 2.8 & 35.428 \\
0.001 & 4.5 & 33.750 \\
0.005 & 17.5 & 32.250 \\
0.010 & 33.7 & 31.000 \\
0.100 & 326.0 & 31.000 \\
0.500 & 1625.0 & 32.000 \\
1.00 & 3250.0 & 36.000
\end{tabular}


Table 8.--Composition of the salt mixture in the mineral control diet for the almond moth and amounts of each cation supplied.

\begin{tabular}{lcccc}
\hline Sa1t & $\begin{array}{c}\text { \% sa1t } \\
\text { in mixture }\end{array}$ & $\begin{array}{c}\text { \% sa1t } \\
\text { in diet }\end{array}$ & $\begin{array}{c}\text { Cation in } \\
\text { diet in mg }\end{array}$ & PPM \\
\hline K2HPO4 & 31.75 & 0.66 & 0.1964 & 1964.0 \\
KH2PO4 & 34.25 & 0.68 & 0.1974 & 1974.0 \\
MgSO4 & 18.00 & 0.34 & 0.0720 & 720.0 \\
Ca (H2PO4)2 & 6.00 & 0.14 & 0.0259 & 259.0 \\
NaC1 & 6.00 & 0.10 & 0.0493 & 493.0 \\
Fe2(SO4)3 & 3.00 & 0.05 & 0.0085 & 85.3 \\
MinSO4 & 0.40 & 0.01 & 0.0034 & 34.2 \\
ZnC12 & 0.40 & 0.01 & 0.0049 & 49.2 \\
CuSO4 & 0.25 & 0.004 & 0.0012 & 12.8 \\
\hline
\end{tabular}

a11 salts ale reagent grade. 
Table 9.--Minimal requirements of the almond moth for cations of minera1 salts and estimated toxicities.

\begin{tabular}{|c|c|c|c|c|c|}
\hline Minerals & $\begin{array}{l}\text { Supple } \\
\text { diet } \\
\text { lev }\end{array}$ & $\begin{array}{l}\text { emented } \\
\text { original } \\
\text { vels }\end{array}$ & $\begin{array}{l}\text { Unsupplemented } \\
\text { diet original } \\
\text { levels }\end{array}$ & $\begin{array}{l}\text { Minima1 } \\
\text { leve1s }\end{array}$ & $\begin{array}{l}\text { Estinated } \\
\text { toxicities }\end{array}$ \\
\hline & $\mathrm{Ng} / 100$ & g PPM & PPMI & $\mathrm{Mg} / 100 \mathrm{~g}$ & $\mathrm{Mg} / 100 \mathrm{~g}$ \\
\hline $\mathrm{K}$ & .750 & 2180.0 & 26.4 & $.325^{\prime}$ & $.450-.650$ \\
\hline $\mathrm{Mg}$ & .250 & 578.0 & 85.0 & .100 & $.150-.200$ \\
\hline $\mathrm{Ca}$ & 1.500 & 2390.0 & 4.1 & 1.000 & -- \\
\hline $\mathrm{Na}$ & .002 & 108.0 & 99.0 & .002 & - \\
\hline $\mathrm{Fe}$ & .01 & 21.0 & 2.0 & .01 & -- \\
\hline $\mathrm{Zn}$ & .001 & 6.0 & 1.6 & .0001 & .001 \\
\hline Mn & .100 & 326.0 & 1.8 & .100 & -- \\
\hline $\mathrm{Cu}$ & .005 & 12.8 & 0.25 & .005 & -- \\
\hline
\end{tabular}




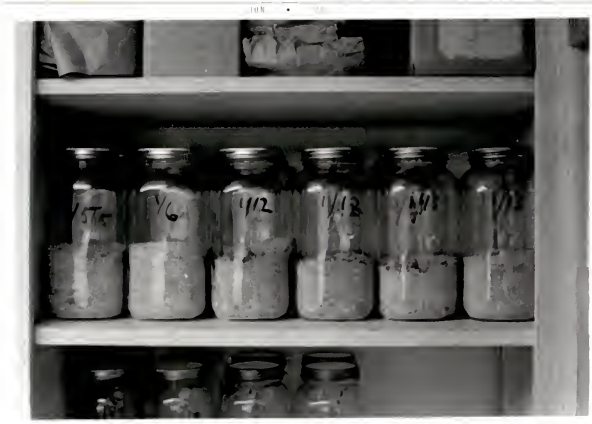

Figure 1.--Laboratory colony of the almond moth on standard laboratory rearing medium. 


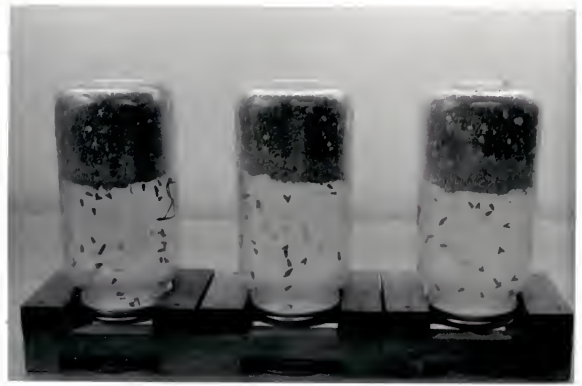

Figure 2.--Egg collecting set up for the almond moth. 


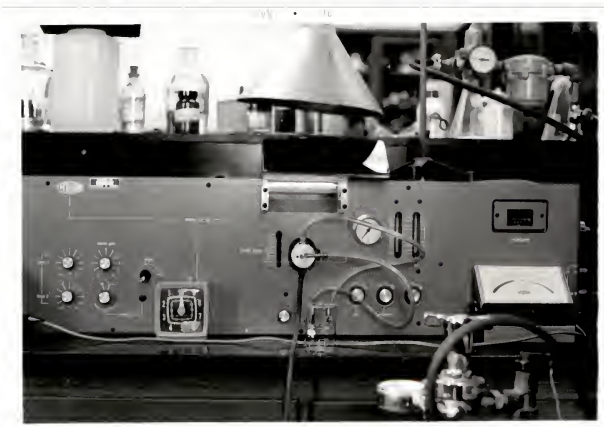

Figure 3.--Mode1 100 Varian Atomic Absorption Spectrophotometer. 


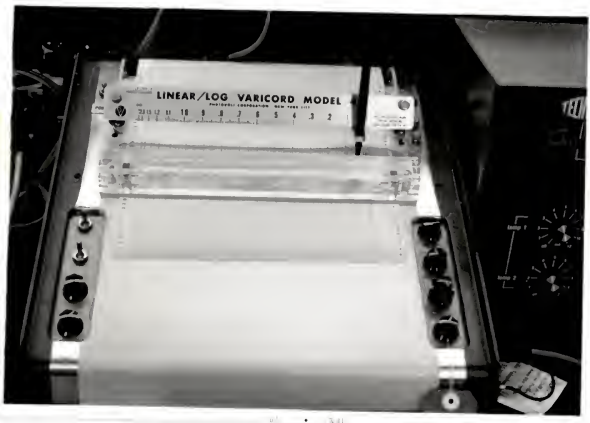

Figure 4.--Mode1 43 Varicord recorder. 


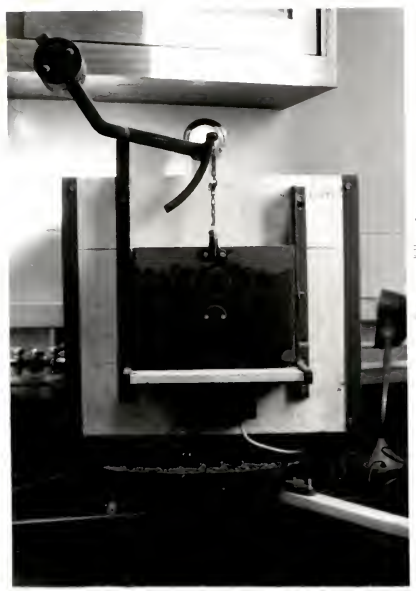

Figure 5.--Boekel Muffle Furnace. 


\section{CHAPTER VII}

\section{SUMMARY}

Requirements for eight mineral salts in the almond moth, Cadra cautella Walker, have been determined. A series of deletion tests using a basal diet with graded levels of minerals plus spectrophotometric analysis of whole insect tissue and standard laboratory rearing medium showed the larvae to require: ( $\mathrm{mg} / 100 \mathrm{~g}$ dry diet) potassium .325; maganesium .100; calcium 1.0; sodium .002; iron .01; zinc .0001; magnesium .100 and copper .005.

Composition of mineral salts in the control (basal) diet and cation composition were determined. Mineral requirements for the alnichd moth were compared with other organisms as well as estinations of tcxicities for potassium, magnesium and zinc.

In conjunction with the mineral studies, semi-optimal levels of amino acids were determined. They were found to be some of the same amino acids required in the rat. The almond moth requires $(\mathrm{mg} / 100 \mathrm{~g}$ dry diet) arginine .6; histidine .5; isoleucine .5; leucine .7; 1ysine 1.0; methionine .3; phenylalanine 1.0; threonine .3; tryptophan .2; valine .4; glutamic acid .5; glycine .4 and cystine . 1 . 


\section{REFERENCES CIIED}

Bach, F. A. 1930. Ephestia elute1la Hubnen, a now pest of curct tobacco in U.S. J. Econ. Entomo1. 23: 1004-1006.

Beck, S. D. 1956. The European corn borer, Pyrausta mulinlis (Hutun) and its principal host plant. II. The irfluence of nutitione? factors on larval growth and development on the corn plat. Ann. Entomo1. Soc. Amer. 49: 582-588.

Beck, S. D., G. M. Chippendale and D. E. Swinton. 1968. Nutrition of the European corn borer, Ostrina nubilalis. VI. A larval rearing medium without crude factors. Ann. Entomo1. Soc. Amer. 61 : $459-462$.

Beck, S. D. and G. G. Kapadia. 1957. Insect nutrition and metabo1ium of sterols. Science.126(3267)L 258-259.

Beck, S. D. and J. Stauffer. 1950. An aseptic method for rearing corn borer larvae. J. Econ. Entomo1. 33: $4-6$.

Bernard, R. and A. Lemonde. 1949. Sugar requirements, Tribolium confusum Duva1. Duva1 Review Canadienne Bio1. 8: $\frac{193-503 .}{49}$

Casperi, E. 1941. Influence of low temperature on the population of Ephestia kuehnie11a. J. Exp. Zoo1. 86: 321-331.

Champ, B. R. 1966. Insects and mites associated with stored products in Queensland. 2. Lepidoptera of Queensland. J. Agr. Anim. Sci. $23:-155-175$.

Chang, T. L., T. A. Grover and W. W. Harrison. 1966. Determinations of Magnesium and Zinc in human brain tissue by atomic absorption spectroscypy. Ana1. Chem. Acta. 34:17.

Chang, T. L. and R. J. Knox. 1967. Determination of phosphate in biological materials and reation mixtures by atomic absorption spectrophotometry. Ana1. Biochem. 20: 282.

Chapmen, R. N. 1923. Nutritional studies on the confused flour beetle, Tribolium confusum. J. Gen. Physio1. 6: 565-585.

Cnavdary, $k . D$. and A. Lemonde. 1962. Phosphorus in the nutrition of Tribolium confusum Diva1. Can. J. Z001. 40: 375-380. 
Chirigos, M. A., A. N. Meiss and J. J. Pisano. 1960. Growth responses of the confused flour beetle, Tribolium confusum (Duva1) to six protein sources. J. Nutr. 72: 121-130.

Clark, A. J. and K. Block. 1959. The absence of sterol synthes is in insects. J. Bio1. Chem. 243: 2578-2582.

Dadd, R. H. 1960. Observations on the palatability and utilization of food of locuts, with particular references to the interpretation of performance of growth trials using synthesis diets. Entomol. Exp. Appl. 3: $283-304$.

1961 The nitritinnal requirements of locusts - V. J. Insect Physio1. 6: 124-125.

1963. Feeding behavior and nutrition in grasshoppers and locusts. * Insect Physio. Vol. I.

Dadd, R. H. and T. E. Mittler. 1966. Permanent culture of an aphid on a totally synthetic diet. Separatum Experimentia. 22: 1-4.

Davis, G. R. F. 1956. Amino Acid requirements of Oryzaephylus surinamensis
(Coeleoptera: Silvaniidae) for pupation. Can. J. Zoology. $34: 82-65$.

Earle, N. W., A. B. Walker, and M. L. Burks. 1966. An artificial diet for the boll weevil Anthonomus grandis (Coleoptera) based on the amino acids in cotton. Ann. Entomo1. Soc. Amer. 59: 664-669.

Earle, N. U.., B. Slaten and M. L. Burks. 1967. Essential fatty acids in the diet of the boll weevil Anthonomus grandis, Boheman. J. Insect Physio1. 13: 187-200.

E1we11, V. T. and J. A. F. Gidley. 1962. Atomic absorption spectrophoiometry. The Macmillan Company, New York.

Ethelston, J. D. 1964. Investigations on ecology and biological control of Ephestia elutella in stored semi-mature Turkish tobacco. S. Afr. Dept. of Agr. Communication. 12: 1-5.

Fast, P. G. 1964. Insect lipids review. Entomol. Soc. Amer. 37: 1-50.

Feldman, F. J. and E. C. Knoblock. 1967. The determination of chromium in biological materials by atomic absorption spectroscopy. Anal.
Chem. Acta. 38: 489 .

Franke1, G. S. 1958. The effects of $z$ inc and potassium in the nutrition of Tenebrio molitor, with observations on expression of carnitine difficiency. J. Nutr. 65: 361-395. Franke1, G. S. 1959a. A historical and comparative survey of the
dietary requirements of insects. Ann. N. Y. Acad. Sci. 77: 267-274.

- 1959b. The chemistry of host specificity of phytophagous insects. Proc. Int. Congr. Biochem. 4 th Congress Vienna, 1958. 
Franke1, G. S. and M. B.lewett. 1946a. The dietetics of the clothes moth, Iineola bisselliella, Hum. J. Exp. Biol. 22: 156-161.

- 1946b. The dietetics of the caterpillars of three Ephestia species, E. kuehrie11a, E. elute11a, and E. cautella, and of a closely rêlated species, Plodia interpunctella. J. Exp. Biol. 22: $162-171$.

- 1946c. Lenoleic acid, vitamin and other fat-soluble substances in the nutrition of certain insects, Ephestia kuehnie11a, E. $\frac{\text { eiule11a, E. caute1la }}{\text { Biol. } 22:}$ and Plodia intervunctelle (Lep.) ${ }^{-} \mathrm{J}$. Exp.

Franke1, G. S. and G. E. Printy. 1954. The amino acid requirements of the confused flour beetle, Tribolium confusum Duval. Biol. 106: 149-157.

Frient, W. G. 1962. Nutrition requirements of phytophagus insects. Ann. Rev. Entomol. 3: 57-74.

Friend, W. G., R. H. Backs and L. M. Cass. 1957. Studies on amino acid requirements of the onion maggot, Hylemya antiqua ( $\mathrm{Mg})$, under aseptic conditions. Can. J. Zoo1. 35: $535-543$.

Friend, W. G., E. H. Salkeld and I. L. Stevenson. 1959. Nutrition of the onion maggot larvae of Hylemya antiqua (Meig) with reference to other members of the genus Hylemya. Ann. N. Y. Acad. Sci. 77: $384-393$.

Gordon, H. T. 1959. Minimal nutritional requirements of the corman cockroach Blate11a germanica L. Ann. N. Y. Acad. Sci. 77: 290351 .

Hamamura, Y., K. Hayashya and K. I. Naito. 1961. Food selection by silkworm larvae Bombyx mori. Nature. 190: 879-881.

Hinton, T., D. T. Noyes and J. E11is. 1951. Amino acids and growth factors in a chemically defined medium for Drosophila. Physiol. Zool. 24: 379.

Hobson, P. R. 1935. On a fat soluble growth factor required by the blowfly larva. Biochem. J. 29: 1292-1926.

House, H. L. 1959. Nutrition of the parasitoid Pseudosurcophara affinis (Fa11) and of other insects. Ann. N. Y. Acad. Sci. 77 :

- 1961. Insect Nutrition. Ann. Rev. Entomo1. 6: 13-26.

- 1962. Insect Nutrition. Ann. Rev. Biochemistry. 31: 653-674.

Ishiis, K., J. N. Kaplauis and W. E. Robbins. 1963. Distribution and fate of $\mathrm{C}-14$ cholesterol in adult mole American cockroach. Ann. Entomo1. Soc. Amer. 56(1): 115-119. 
Jensen, J. 1962. Free acids, metabolic rate and selected histology of methionine-deficient Tribolium conéusum. Dissert. Abstr. 22: $2852-2853$.

Jones, J. H. and C. Foster. 1942. A salt mixture of use with basal diets either low or high in phosphorous. J. Nutr. 24: 245-256.

Levinson, A. H. 1955. Nutritional recuirements of insects. Rivista Parasit. 16: 113-183.

- 1960. The function of dietary sterols in phytophagus insects. Int1. Kongr. Entomo1., 11th. Kongr. Wein. 1960. 3: 145-153. 1962. Function of dietary sterols in phytophagus insects. J. A
Insect Physiol. 8: 191-198.

Lipke, H. and G. Franke1. 1956. Insect Nutrition. Ann. Rev. Entomo1. 1: $17-44$.

Loeb. J. 1915. The salts required for the development of insects. J. Biol. Chem. 23: 431-433.

Medici, J. 1964. Nutritional studies including quantitative aruino acid and mineral salt requirements with the flour beetle, Tribolium confusum (Duva1). Doctoral dissertation, Rutgers University.

Medici, J. and M. W. Taylor. 1966. Mineral requirements of the confused flour beetle, Tribolium confusum (Duva1). J. ITutr. 88(2): 181-186.

1967. Interrelationships among copper, zinc and cadnium in the diet of the confused flour beetle. J. Nutr. 93(3): 307-309.

Moore, W. 1946. Nutrition of Attagenus sp. (Coleoptera: Dermestidae). Ann. Entomo1. Soc. Amer. 39: 513-521.

Naylor, A. F. 3.963. Glutanic and aspartic acids and sucrose in the diet of the flour beetle, Tribolium confusum (Tenebridiidae). Can. J. Zoo1. 41: 1127-1132.

Nat. Acad. Sci., Nat. Fes. Council Pub. 989 (1962). Nutrient requirements of labortatory animals. $95 \mathrm{pp}$.

Nat. Acad. Sci., Nat. Res. Council Pub. 827 (1960). Nutrient requirements of poultry. $32 \mathrm{pp}$.

Patton, R. I. 1963. Introductory Insect Physiology. W. B. Saunders Company, Philadelphia, Pa. 245 pp.

Pausch, R. D. 1962. Nutrition of the larvae of the oriental rat flea Xenophylla cheopis $R$. with additional notes on bionomics. Dissert. Abstr. 23: $75 ;-760$. 
Rock, G. C. and K. W. King. 1966. Amino acid composition in carbohydrates of the red banded leaf roller Argystaenia velutimana (Lepidoptera: Tortricidae) duing development. Ann. Entomol. Soc. Amer. $59:$ : 373-377.

- 1967. Estimaticrs by carcass analysis of the growth requirements for amiro acias in the codling moth, Carposcapsa pomonella Lepidoptera: Olethrentidae). Ann. Entono1. Soc. 60: 1161 1162 .

- 1968. Amino acid synthesis from giucose-U-14-C in Argyrotaenia velutinana (Lepidoptera: Tortricidae) larvae. J. Nutr. $35:$ $369-373$.

Rodriguez, J. G. 1964. Nutritional studies in the Acerina. Acarologia 6: $324-337$.

- 1966. Axenic Arthropoda: Current status of research and future possibilities. Ann. N. Y. Acad. Scj. 139: 53-64.

Rodriguez, J. G. and R. E. Hampton. 1966. Essential amino acids determined in the two spotted spider mite, Tetranychus urticae Kock. (Acarina: Tetranychidae) with glucose-U-C-14. J. Insect. Physioi. 12: $1209-1216$.

Rose, W. C. 1938. Amino acids in nutrition. Physio1. Rev. 18: 109-136.

Sang, J. If. 1956. The qualitative nutritional requirenent s of Drosophila melanogaster. J. Exp. Biol. 33: 45-72.

Savarama Sastry, K., R. Radha Krishn Murty and P. S. Sarna. 1958. Studies of zinc toxicities in the larvae of the rice noth Coreyra cephelonica. J. Biochem. 69: 425-423.

Steinhaus, E. A. and C. R. Be11. 1953. The effects of certain microorganisms and antibiotics on stored-grain pests. J. Econ. Entomo1. 1,6: 583-598.

Strong, R. G., G. J. Partida and D. N. Warner. 1968. Rearing storedproduct insects for laboratory studies: six species of moths. J. Econ. Entomo1. 6i: 1238-1249.

Stee1, R. G. D. and J. H. Torrie. 1960. The Principles and Procedures of Statistics. McGraw Hi11 Book Company, New York.

Taylor, M. W. and J. C. Medici. 1966. Arino acid requirements for grain beetles. J. Nutr. 88: 176-180.

Thorsteinson, A. J. 1960. Mineral salt requirements in the rice moth Coreyta cepheionica (Staint). Comp. Biochem. Physiol. 9: 46-50.

Vanderzant, E.S. 1958. The amino acid requirement of the pink bollworn. J. Econ. Entomo1. 5i: 309-311. 
1963. Iutrition of the boll weevil 1arvae. J. Econ. Entomol. 56: $357-362$.

Wadsworth, R. V. 1933. Cocoa Leans and Ephestia elute11a. Trop. Agr. 10: $9 \%-100$.

Waites, R. E. and S. Gothilf. 1969. Nutrition of the almond moth. I. Analysis and inprovenent of the experituental diet. J. Econ. Entomol. 6? 301-305.

Wa11ey, J. E. S. 1960. Cadra cautelia (Whalker) new combination. Entomologists Gazette 11: $\frac{183-184 .}{10}$

Whiting, P.W. 1921. Rearing meal moths and parasitic wasps for experimental purposes. J. Heredity 12: 255-261.

Williams, J. I. 1938. Mating of Ephestia kuehniella and its results. Eritomo1. News. 49: 10/4-107.

Willis, J. B. 1965. Analysis of biological materials by atomic absorption spectroscopy. Clin. Chem. 11: 251.

Zangg, W. S. and R. J. Knox. 1967. Determination of phosphate in biological materials by atomic absorption spectrophotometry. Anal. Biochem. 20: 282. 


\section{BIOGRAPHICAL SKETCH}

William Craig Stevens was born August 23, 1938, at Olive lii11, Kentucky; the son of W. E. and Mary Stevens. After graduating from Olive Hill High School in May of 1957, he attended Morehead State University and received the Bachelor of Science degree in May of 1962 with a major in chemistry and biology. Following graduation, he attended the University of Louisville where he received the Masters degree in Zoology in August of 1963. He tought general biology at Western Kentucky University at Bowling Green, Kentucky, from 1963 to 1966. He married the former Sharon A. Curling of Cadiz, Kentucky, June 18, 1967. Work began toward the doctorate degree in 1966 at the University of Kentucky and 1967 at North Carolina State University at Raliegh, North Carolina. Work was continued during 1968-1970 at the University of Florida where the degree of Doctor of Philosophy was awarded in August 1970. 
This dissertation was prepared under the direction of the chairman of the candidate's supervisory committee and has been approved by all members of that committee. It was submitted to the Dean of the Co1lege of Agriculture and to the Graduate Council, and was approved as partial fulfillment of the requirements for the degree of Doctor of Philosophy.

August, 1970

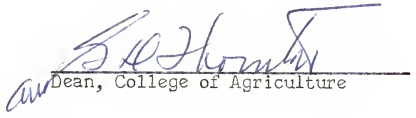

Dean, Graduate School

Supervisory Committee:

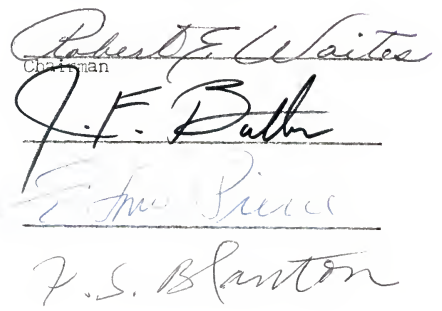

